\title{
APPLICATION OF THE DIAPER USE RATING SCALE IN A MEDICAL CLINIC OF A UNIVERSITY HOSPITAL
}

\author{
Felippe Sales Freitas Araújo ${ }^{1, *}$ (D), Karina Chamma Di Piero² (i), Camila Castanho Cardinelli² (D)
}

\begin{abstract}
Objectives: apply the evaluation scale for the use of diapers and absorbent products (AUFA Scale) in patients admitted to the medical clinic; identify and analyze the results of this application, the sociodemographic profile of patients in vogue as well as repercussions on the skin related to the use of sanitary pads and diapers. Method: observational, cross-sectional, descriptive and exploratory study, carried out in the medical clinic sector of the University Hospital Hospital Universitário Clementino Fraga Filho (HUCFF/UFRJ), from November 2019 to February 2020 , with a convenience sample of 46 patients. There was application of a form to survey general data and, later, the application of the AUFA scale, which identified the following variables: skin conditions, skin aging, cognitive ability, motor skills and incontinence. Results: all 46 patients were using diapers, half women and the other half men, mostly elderly and without a diagnosis of incontinence. In view of the application and analysis of the AUFA scale, only 18 patients (39.14\%) were indicated for diaper use. With the inappropriate use of diapers, 27 patients had skin lesions resulting from moisture, a situation that was justified by the absence of systematic care observation for the prevention and treatment of dermatitis associated with incontinence in the evaluated patients. Conclusion: the use of the AUFA scale is indicated to identify patients who need to wear diapers, delimiting care with their management and thus preventing complications and worsening of incontinence.
\end{abstract}

DESCRIPTORS: Nursing. Nursing care. Urinary incontinence. Sanitary pads. Prevention of diseases. Stomatherapy.

\section{APLICAÇÃO DA ESCALA DE AVALIAÇÃO DO USO DE FRALDAS EM UMA CLÍNICA MÉDICA DE UM HOSPITAL UNIVERSITÁRIO}

\begin{abstract}
Objetivos: aplicar a escala de avaliação do uso fraldas e absorventes (AUFA) nos pacientes internados na clínica médica; identificar e analisar os resultados dessa aplicação, o perfil sociodemográfico dos pacientes em vogo bem como repercussões à pele relacionadas ao uso de absorventes e fraldas. Método: estudo observacional transversal, descritivo e exploratório, realizado no setor de clínica médica do Hospital Universitário Clementino Fraga Filho (HUCFF/UFRJ), no período de novembro de 2019 a fevereiro de 2020, com amostra por conveniência de 46 pacientes. Ocorreu aplicação de ficha para levantamento de dados gerais e, após, a AUFA, que identificou as seguintes variáveis: condições da pele, envelhecimento da pele, capacidade cognitiva, capacidade motora e incontinências. Resultados: todos os 46 pacientes encontravam-se em uso de fralda, sendo metade mulheres e a outra metade homens, em grande maioria composta de idosos e sem diagnóstico de incontinência. Diante
\end{abstract}

1. Universidade Federal do Rio de Janeiro - Hospital Universitário Clementino Fraga Filho - Residência Multiprofissional em Clínica Médica - Rio de Janeiro (RJ), Brazil.

2. Universidade Federal do Rio de Janeiro - Hospital Universitário Clementino Fraga Filho - Comissão de Métodos Relacionados à Integridade da Pele - Rio de Janeiro (RJ), Brazil.

*Correspondence author: felippesales-@hotmail.com

Section Editor: Gisela Maria Assis

Received: Jul. 2021, 23 | Accepted: Sept. 2021, 15

How to cite: Araújo FSF; Di Piero KC; Cardinelli CC. Application of the diaper use rating scale in a medical clinic of a university hospital. ESTIMA, Braz. J. Enterostomal Ther., 2021, 19: e2221. https://doi.org/10.30886/estima.v19.1114_IN 
da aplicação e análise da AUFA, apenas 18 pacientes $(39,14 \%)$ tinham indicação para uso de fraldas. Com o uso inadequado da fralda, 27 pacientes apresentaram lesão de pele decorrente de umidade, situação que se justificou pela ausência da observação de cuidados sistematizados para prevenção e tratamento de dermatite associada à incontinência nos pacientes avaliados. Conclusão: indica-se o uso da escala AUFA para identificar os pacientes que necessitam usar fralda, delimitando cuidados com seu manejo e prevenindo, assim, complicações e agravamentos da incontinência.

DESCRITORES: Enfermagem. Cuidados de enfermagem. Incontinência urinária. Absorventes higiênicos. Prevenção de doenças. Estomaterapia.

\section{APLICACIÓN DE LA ESCALA DE EVALUACIÓN DEL USO DE PAÑALES EN UNA CLÍNICA MÉDICA DE UN HOSPITAL UNIVERSITARIO}

\section{RESUMEN}

Objetivos: aplicar la escala de evaluación del uso pañales y toallas sanitarias (AUFA) en los pacientes internados en la clínica médica; identificar y analizar los resultados de esta aplicación, el perfil sociodemográfico de los pacientes en estudio, así como repercusiones para la piel relacionadas al uso de toallas sanitarias y pañales. Método: estudio observacional transversal, descriptivo y exploratorio, realizado en el sector de clínica médica del Hospital Universitario Clementino Fraga Filho (HUCFF/UFRJ), en el período de noviembre del 2019 a febrero del 2020, con muestra por conveniencia de 46 pacientes. Ocurrió la aplicación de ficha para el levantamiento de datos generales y, después, la AUFA, que identificó las siguientes variables: condiciones de la piel, envejecimiento de la piel, capacidad cognitiva, capacidad motora e incontinencias. Resultados: los 46 pacientes se encontraban en uso de pañal, siendo mitad mujeres y la otra mitad hombres, en gran mayoría compuesta por ancianos y sin diagnóstico de incontinencia. Ante la aplicación y análisis de la AUFA, solamente 18 pacientes (39,14\%) tenían indicación para el uso de pañales. Con el uso inadecuado del pañal, 27 pacientes presentaron lesión de piel derivada de humedad, situación que se justificó por la ausencia de la observación de cuidados sistematizados para prevención y tratamiento de dermatitis asociada a la incontinencia en los pacientes evaluados. Conclusión: se indica el uso de la escala AUFA para identificar a los pacientes que necesitan usar pañal, delimitando cuidados con su manejo y previniendo, así, complicaciones y agravamientos de la incontinencia.

DESCRIPTORES: Enfermería. Cuidados de enfermería. Incontinencia urinaria. Toallas sanitarias higiénicas. Prevención de enfermedades. Estomaterapia.

\section{INTRODUCTION}

The object of this study is the nursing actions related to the management of incontinence in relation to the use of absorbent devices and diapers, in addition to the prevention of dermatitis associated with incontinence in patients admitted to the internal medicine sector of a university hospital located in the city of Rio de Janeiro.

Absorbent devices for adult use are considered in the scientific literature as tools added to health care. From this perspective, its incorporation into health care demands clinical judgment and constant reassessment of care practices.

The nurse needs to be grounded and instrumentalized in the proper indication and continuity regarding the use of these devices in clinical practice, aware that this practice brings benefits and harms, such as incontinence-associated dermatitis (IAD), pressure injury, urinary infection , worsening of incontinence, among others ${ }^{1-6}$.

In this sense, it is necessary to use scales and assessment instruments to support conscious decision-making based on scientific evidence by nurses regarding the use of pads and diapers ${ }^{1-6}$.

Thus, the evaluation scale for the use of diapers and absorbent products (AUFA) is adequate for being a systematic tool for indicating and evaluating the need for the use of absorbent devices, as well as helping to implement preventive measures for IAD, according to the determination of the patient's risk score ${ }^{1-6}$. 
Furthermore, when applying this scale, there is a score with an algorithm that helps and supports the choice of the appropriate absorbent device. Thus, if the final score is less than 11 , there is no indication for the use of absorbent devices, and the use of external utensils, such as bedpans, urinals or toilets, is suggested. In this case, urinary or fecal loss is absent or less than $50 \mathrm{~mL}$ a day, associated with preserved cognitive capacity ${ }^{1}$.

However, if the result is greater than or equal to 11 points and less than 14 points, it is indicated that there is urinary or fecal loss between 50 and $900 \mathrm{~mL}$ per day, correlated with partial cognitive deficit, therefore, there is a need to use absorbents ${ }^{1}$.

Finally, if a quotient greater than or equal to 14 points on the AUFA scale is reached, it is revealed that there is urinary or fecal loss greater than or equal to $900 \mathrm{~mL}$ per day, with severe cognitive deficit. Therefore, it is recommended to use diapers ${ }^{1}$.

Therefore, the AUFA scale guides nurses' decision-making, enabling the planning of systematized and individualized care, with the main elements analyzed being: cognitive and motor capacity, degree of incontinence, patient and caregiver preferences, number of exchanges and conditions of skin - aging and skin integrity ${ }^{1-6}$.

It is worth remembering that the breakdown of skin integrity represents a health problem that can directly interfere with people's quality of life, functional capacity, autonomy and independence. When associated with any chronic diseases, it further increases the vulnerability to infectious pathological processes that can culminate in hospitalization. Thus, prevention is the best alternative, and health professionals, especially nurses, are responsible for preventive interventions and early treatment of associated injuries ${ }^{7}$.

It is worth noting that in recent years, with technological advances in health, there has been a significant increase in the life expectancy of the world population, and, therefore, a change in the profile of patients under health care, with more advanced ages, suffering from chronic diseases and risk for skin lesions ${ }^{6-8}$.

With regard to urinary, fecal and double (urinary and fecal) incontinence, the use of diapers or pads can be considered responsible for the emergence of dermatological problems and expansion of incontinence episodes. Thus, the indication for such use must be individually evaluated by the nurse through scientific strategies. The choice of the absorbent device must occur according to the analysis of the patient's characteristics, such as weight and height, as well as the type of incontinence? .

Thus, the type, shape, capacity and absorption speed of the absorbent or diaper and the saturation period, odor inhibitors and the need for changes are points to be considered when choosing the device, according to the demand of the client's profile. ${ }^{9}$

However, in everyday practice, the use of this individual assessment is not routine in inpatient units. It is not possible to determine whether the parameters designated by manufacturers as an indication of use for each subgroup are in line with the technical parameters of the International Continence Society (ICS). Therefore, the use and empirical indication can have negative consequences for the patient and high cost for the health institution?.

In this sense, the following question was delimited as a guiding question: how is the indication for the use of diapers and sanitary pads by applying the AUFA scale to patients hospitalized in the clinical sector of a university hospital in Rio de Janeiro?

To answer the above question, the following objectives were defined: to apply the AUFA scale to patients admitted to the medical clinic; identify and analyze the results of this application, the sociodemographic profile of patients in vogue as well as repercussions on the skin related to the use of sanitary pads and diapers.

\section{METHOD}

This is a cross-sectional, descriptive and exploratory observational study carried out at the University Hospital Hospital Universitário Clementino Fraga Filho (HUCFF) of the Universidade Federal do Rio de Janeiro (UFRJ) University.

The method used was observational, with a cross-sectional design, with a time interval for conducting the research being determined, enabling a portrait of the momentary reality ${ }^{10}$. 
The descriptive and exploratory character describes characteristics of the population, phenomena, experience reports through observations, records, analyses, classifications and understanding of the acts, without interfering with the analyzed reality, clarifying concepts and ideas ${ }^{11}$.

The study setting was the medical clinic sector of the HUCFF/UFRJ, located in the city of Rio de Janeiro. This sector has 46 beds, divided into 2 wards, one female and one male with the same number of beds.

The participants were patients admitted to the medical clinic unit of that hospital. This study addressed all hospitalized patients during the period of data collection. Thus, there were 46 participants, of both genders and aged 18 years or over, who, during the period of data collection, accepted by free choice to participate in the research and signed the free and informed consent form.

All patients who participated in the study were assured the legal and ethical precepts, based on the approval of the Research Ethics Committee of the HUCFF/UFRJ, CAAE no 31521220. 4.0000.5257 and opinion number 4.268.134.

Data collection took place between November 2019 and February 2020 through the application of a form for general data collection containing: gender, age, race, underlying diseases and reason for current hospitalization.

After identifying the sample, the AUFA ${ }^{\circledR}$ Scale was applied. Complementarily, the Mini Mental State Examination Scale (MMSE) and the International Consultation on Incontinence Questionnaire/Short FORM (ICIQ-SF) were applied, both to confirm situations related to cognition and identified incontinence.

About the AUFA scale, it is clarified that it emerged as the product of a master's research, being updated and validated by a doctoral research in nursing ${ }^{1}$.

The AUFA scale assesses patient/caregiver preferences, number of exchanges, skin integrity, skin aging, cognitive ability, motor ability and incontinence, with scores between 1 and 3 for each item, with the final score being the sum of the points: $<11$ points - no indication for the use of hygienic pads or diapers; $\geq 11$ and < 14 points - indication of use of sanitary pads; $\geq 14$ points - indication for use of diapers; < 17 points - lower risk of IAD; $\geq 17$ points - increased risk of IAD ${ }^{1}$ (Fig. 1).

Complementarily, the MMSE instruments (Fig. 2) and ICIQ-SF (Fig. 3) were used below:

The treatment and analysis of the data took place in two parts: the elements from the first phase of the data collection instrument, which consists of the survey participant's general data collection form, were included and analyzed in the Microsoft Excel ${ }^{\circledR} 2007$ software, giving origin of the identification data of the population.

Comparing the data from the application of the AUFA ${ }^{\circledR}$ Scale, tables were built in Word ${ }^{\circledR}$ to analyze and compare scores and complementary data based on the MMSE and ICIQ-SF.

\section{RESULTS}

Of the 46 participants analyzed, 23 (50\%) patients were male and 23 (50\%) were female. Ages ranged between 40 and 99 years, with higher prevalence in the age group 60 to 69 years. Twenty-one participants (45.65\%) declared themselves white and 25 (54.35\%) black.

About the level of education, all had incomplete elementary school. As for the reason for admission, all had systemic arterial hypertension, the vast majority being hospitalized for stroke, followed by acute myocardial infarction and dyspnea, as shown in the table below for the characterization of the population studied (Table 1).

When applying the AUFA scale, it was observed that $100 \%$ of the participants used diapers, with 28 (60.86\%) having no indication for the use of absorbent devices and 18 (39.14\%) had a score compatible with the use of diapers or absorbent devices.

Therefore, there was a tendency to use the diaper without prior scientific judgment by nursing, including interference from the decision made by the patient, their family and/or caregiver, who also did not present scientific justification for their use.

The cognitive capacity of the patients was evaluated using the MMSE scale, with 21 (45.65\%) with a preserved score, 12 (26.09\%) with subjective memory complaints and 13 (28.26\%) with objective memory complaints. This meant an increased risk in more than half of the participants regarding the understanding of the need to use the diaper and its proper use in clinical practice. 


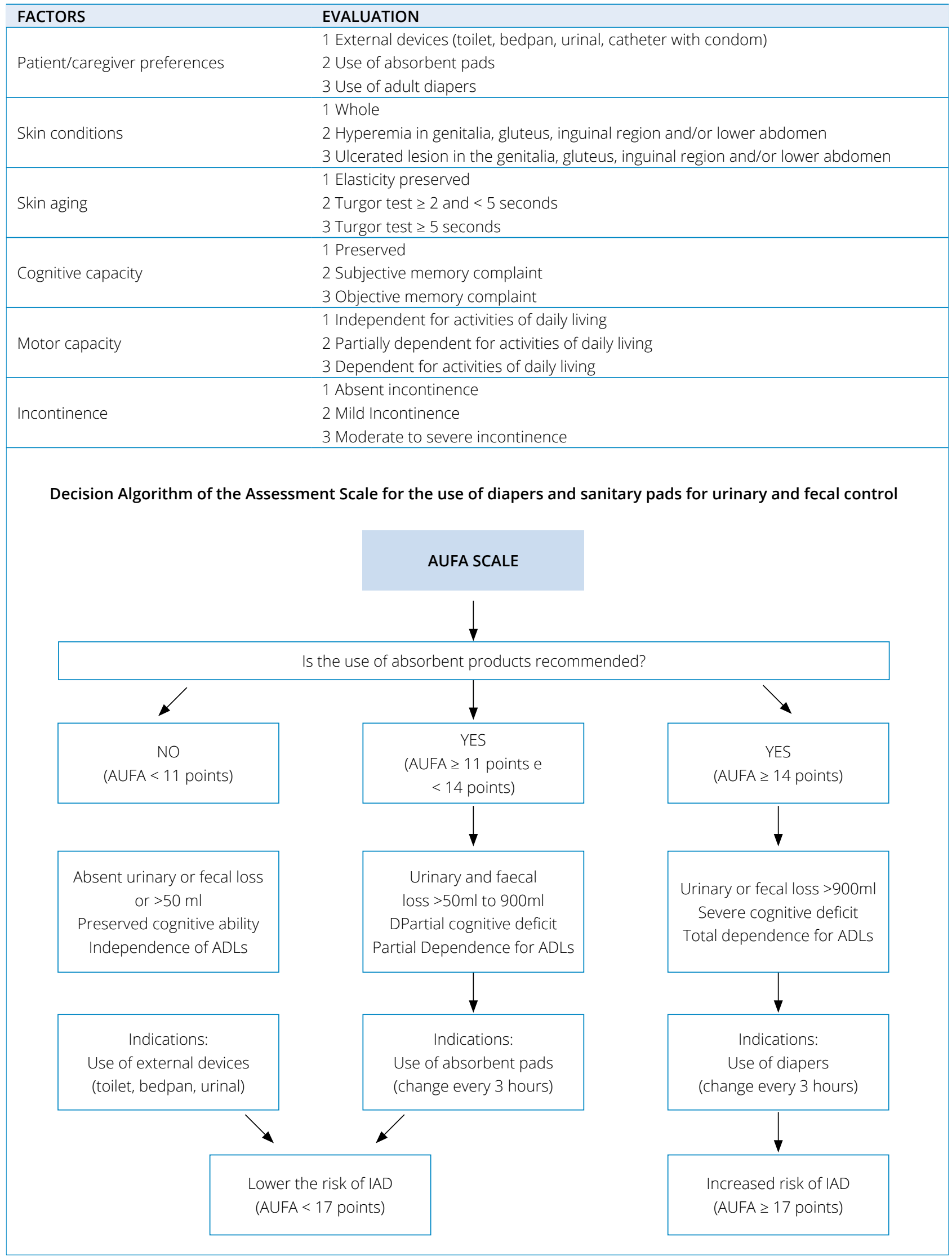

Figure 1. Instrument for indicating the use of sanitary pads or diapers and for assessing the risk of dermatitis associated with incontinence. Rio de Janeiro (RJ) - 2019.

AUFA= (Avaliação do Uso de Fraldas e Absorventes) evaluation of the use of diapers and absorbent products; ADL= Activities of Daily Living; $\mid A D=$ Incontinence Associated Dermatitis. 


\section{GUIDANCE SCORE 01 POINT FOR EACH}

1) What year are we in?

2) What time is it approximately?

3) What day of the month is it?

4) What day of the week are we?

5) What month are we in?

6) Where are we?

7) What floor are we on?

8) What neighborhood are we in?

9) What city are we in?

10) What state are we in?

\section{RECORD 03 POINTS}

11) Mention 3 objects (CUP, SUITCASE and CAR), and ask to repeat. Give one point for each correct answer. Repeat until they learn.

Number of attempts: (if there is "inclusion", describe):

\section{ATTENTION AND CALCULATION 05 POINTS}

12) Series of "7". Give 100 and ask to subtract 7, repeat 5 times $(93,86,79,72,65)$.

Or ask to spell the word world backwards (D-L-R-O-W)

RECALL MEMORY 03 POINTS

13) Ask to repeat the 3 words. Deduct 1 point for each unnamed object. Maximum 6 attempts

LINGUAGEM 09 POINTS

LANGUAGE 09 POINTS

14) Point the pencil and the clock and ask to name them (02 points)

15) Ask to repeat: "not here, not there, not over there" (01 point)

16) Ask to follow a command in three steps: "take this paper with your right hand, fold it in half and put it on the floor" (03 points)

17) Ask to follow the command written on the paper: "close your eyes" (01 point)

18) Write a sentence (must have subject, verb and predicate) (01 point)

19) Ask to copy the design (01 point)

Close your eyes

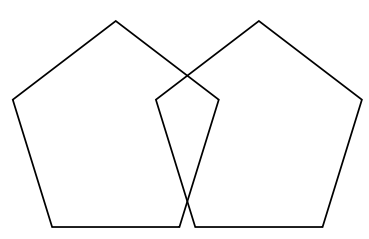

\section{ANIMALS}

( ) Up to 12 different names

( ) Between 13 and 18 names

( ) More than 18 names

Figure 2. Mini Mental State Examination Scale: Cognitive Deficit Assessment. Rio de Janeiro (RJ) - 2019. 


\section{ICIQ-SF}

Name of the Patient:

Date of Today_____ _ _

Many people have urinal loss at some point. We are trying to find out how many people lose urine and how much it upsets them. We would be very thankful if you could answer the following questions, thinking about how have you been feeling in the PAST FOUR WEEKS, approximately.

1. Date of Birth______ (Day/Month/Year)

2. Gender: Female $\square$ Male $\square$

3. How often do you lose urine? (check one answer) Never $\square 0$ Once a week or less $\square 1$ Two or three times a week $\square 2$ Once a day $\square 3$

Several times a day $\square 4$ All the time $\square 5$

4. We would like to know how much urine you think you lose (check one answer)

None $\square 0$ A small amount 2 A moderate amount $\square 4$ A big amount $\square 6$

5. In general, how much does losing urine interfere with your daily life? Please circle a number between 0 (does not interfere) and 10 (it interferes a lot)

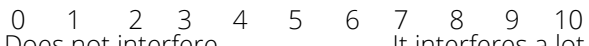
Does not interfere It interferes a lot

ICIQ Score: sum of results $3+4+5=$

6. When do you lose urine? (Please check all alternatives that apply to you)

Never $\square$ aching the toilet $\square$ I lose it when I cough or sneeze $\square$ I lose it when I am sleeping I lose it while I'm doing physical activities $\square$ I lose it when I finished urinating and I'm getting dressed $\square$ I lose for no obvious reason $\square$ I lose it all the time $\square$

Figure 3. International Consultation on Incontinence Questionnaire/ Short FORM scale. Rio de Janeiro (RJ) - 2019.

Table 1. Sample characterization: gender, age, education, medical diagnosis. Rio de Janeiro (RJ) - 2021.

\begin{tabular}{lll}
\hline Gender & Sample & Race/Color \\
\hline Female & $23(50 \%)$ & 12 black $(52.17 \%)$ \\
\hline Male & $23(50 \%)$ & 13 black $(56.52 \%)$ \\
\hline Age & & 10 white $(43.47 \%)$ \\
\hline $40-49$ anos & & \\
\hline $50-59$ anos & $02(4.35 \%)$ & \\
\hline $60-69$ anos & $09(19.56 \%)$ & $14(30.43 \%)$ \\
\hline $70-79$ anos & $12(26.09 \%)$ & \\
\hline $80-89$ anos & $07(15.21 \%)$ & \\
\hline $90-99$ anos & $02(4.35 \%)$ & \\
\hline
\end{tabular}

Incomplete Elementary School (100\%)

continue... 
Table 1. Continuation...

\begin{tabular}{|c|c|c|}
\hline Medical diagnostic & Sample & Common Pathology \\
\hline Stroke & $09(19.56 \%)$ & \multirow{20}{*}{ Systemic Arterial Hypertension(100\%) } \\
\hline Dyspnea & $04(8.70 \%)$ & \\
\hline Acute myocardial infarction & $04(8.70 \%)$ & \\
\hline Digestive hemorrhage & $03(6.52 \%)$ & \\
\hline Nausea and vomiting & $03(6.52 \%)$ & \\
\hline Malnutrition & $03(6.52 \%)$ & \\
\hline Sepsis & $03(6.52 \%)$ & \\
\hline Pyelonephritis & $02(4.35 \%)$ & \\
\hline Hepatic encephalopathy & $02(4.35 \%)$ & \\
\hline LLL Ischemia & $02(4.35 \%)$ & \\
\hline Headache & $02(4.35 \%)$ & \\
\hline Rehabilitation & $01(2.17 \%)$ & \\
\hline Cellulitis & $01(2.17 \%)$ & \\
\hline Palliative radiotherapy & $01(2.17 \%)$ & \\
\hline Vasculitis & $01(2.17 \%)$ & \\
\hline Urethral bleeding & $01(2.17 \%)$ & \\
\hline Pemphigus vulgaris & $01(2.17 \%)$ & \\
\hline Syncope & $01(2.17 \%)$ & \\
\hline Anemia & $01(2.17 \%)$ & \\
\hline Nose melanoma & $01(2.17 \%)$ & \\
\hline
\end{tabular}

LLL= Left lower limb

Regarding activities of daily living, 11 (23.91\%) patients were classified as independent, 12 (26.09\%) partially dependent and 23 (50\%), most of them dependent to develop activities of daily living, a situation that determined the need for the presence of a caregiver, interfering positively or negatively in the introduction of the absorbent device and its handling.

Incontinence was assessed using the ICIQ-SF scale and 30 (65.21\%) patients were found with absence of incontinence, 12 (26.09\%) with mild incontinence and 4 (8.70\%) with moderate and severe incontinence, according to table 2, below:

The survey data showed that damage to skin integrity did not occur in $19(41.30 \%)$ participants, however more than half had some damage, being 09 (19.56\%) grade 1 IAD in areas of genitalia, buttocks, inguinal regions and lower abdomen, and 18 (39.14\%) grade 3 IAD.

This fact may also be related to the use of two or more diapers, a situation that is out of line with good health practices, favoring an increased risk for the development of IAD, pressure injury, urinary infection, among others.

IAD is a common clinical manifestation in patients with incontinence. It is a skin inflammation, characterized by edema, erythema and erosive/macerated lesions of the epidermis. ${ }^{1-3,16}$ due to contact with excretions and moisture, especially in the perineum, genitalia, buttocks, perineal/perianal region, thighs and upper abdomen/adjacencies.

Factors that facilitate or aggravate its installation range from excessive skin moisture, inadequate care in its management, changes in its $\mathrm{pH}$ due to the action of excretions and/or use of hygiene products, in addition to the presence of microorganisms and extrinsic factors such as pressure and friction ${ }^{3,16}$.

Therefore, preventive management aims to remove irritating substances from the skin, in addition to gentle handling, combined with the use of protective skin barriers, that is, systematization of nursing care ${ }^{17}$. 
Table 2. Fatores das escalas: escala de avaliação do uso fraldas e absorventes, Escala Mini Exame do Estado Mental e International Consultation on Incontinence Questionnaire/Short FORM. Rio de Janeiro (RJ) - 2021.

\begin{tabular}{|c|c|c|c|}
\hline $\begin{array}{c}\text { Variable } \\
\text { AUFA SCALE }\end{array}$ & Punctuation & Score & Percentage \\
\hline \multirow{3}{*}{$\begin{array}{l}\text { Patient/caregiver } \\
\text { preference: }\end{array}$} & $\begin{array}{l}1 \text { External devices (toilet, bedpan, urinal, catheter with } \\
\text { condom) }\end{array}$ & 0 & $0 \%$ \\
\hline & 2 Use of sanitary pads & 0 & $0 \%$ \\
\hline & 3 Use of adult diapers & 46 & $100 \%$ \\
\hline \multirow{3}{*}{ Skin Conditions } & 1 Whole & 19 & $41.30 \%$ \\
\hline & $\begin{array}{l}2 \text { Hyperemia in genitalia, gluteus, inguinal region and/or } \\
\text { lower abdomen. }\end{array}$ & 9 & 19. $56 \%$ \\
\hline & $\begin{array}{l}3 \text { Ulcerated lesion in the genitalia, gluteus, inguinal region } \\
\text { and/or lower abdomen. }\end{array}$ & 18 & $39.13 \%$ \\
\hline \multirow{3}{*}{ Skin Aging } & 1 Elasticity preserved & 23 & $50 \%$ \\
\hline & 2 Turgor Test $\geq 2$ and $<5$ seconds. & 21 & $45.65 \%$ \\
\hline & 3 Turgor test $\geq 5$ seconds & 2 & $4.34 \%$ \\
\hline \multirow{3}{*}{$\begin{array}{l}\text { Cognitive ability - MMSE } \\
\text { (incomplete elementary } \\
\text { school) }\end{array}$} & 1 Preserved & 21 & $45.65 \%$ \\
\hline & 2 Subjective memory complaint & 12 & $26.09 \%$ \\
\hline & 3 Objective memory complaint & 13 & $28.26 \%$ \\
\hline \multirow{3}{*}{ Motor Capacity } & 1 Independent for activities of daily living & 11 & $23.91 \%$ \\
\hline & 2 Partially dependent for activities of daily living & 12 & $26.09 \%$ \\
\hline & 3 Dependent for activities of daily living & 23 & $50 \%$ \\
\hline \multirow{3}{*}{ Incontinence - ICIQ } & 1 Absent incontinence & 30 & $65.21 \%$ \\
\hline & 2 Mild incontinence & 12 & $26.09 \%$ \\
\hline & 3 Moderate to severe incontinence & 4 & $8.70 \%$ \\
\hline
\end{tabular}

AUFA= Avaliação do Uso Fraldas e Absorventes; MEEM= Escala Mini Exame do Estado Mental; ICIQ= International Consultation on Incontinence Questionnaire/Short FORM

\section{DISCUSSION}

The analysis of the profile of the participants showed the majority of elderly people, with frequency over 60 years of age, a situation that reaffirms the increase in this age group, which, due to the decline of their physiological functions, already determines an increased risk for complications during hospitalization, especially in a medical clinic sector, with diverse demands and different hospitalized patients ${ }^{18-20}$.

The aging process determines a reduction in functional capacity, susceptibility to chronic diseases and incontinence. In addition, there is also the cognitive portion and level of awareness that impact on autonomy and self-care, exacerbating the subject's vulnerability and passivity towards the caregiver ${ }^{20}$.

Regarding the color variable, most participants were black, a situation that raises the importance of early and more detailed skin examinations due to the complexity of identifying initial changes, such as erythema and elementary lesions difficult to be seen on dark skin.

Regarding the level of education, all participants were at elementary level, and knowing that there is a direct relationship between education, quality of life and health, it was observed that low education made it difficult to understand the factors that affect individual health.

The reasons for the current hospitalization of the participants, as well as the common underlying disease among them, are included in the list of non-communicable chronic diseases, with chronic arterial hypertension being prevalent, together with the complications highlighted in the study - stroke and acute myocardial infarction, as well as dyspnea as a symptom that may be related to cardiopulmonary complications. 
According to Malta et al. ${ }^{21}$, carriers of this group of pathologies use health services twice as much, with greater frequency and prevalence of hospitalization and medical appointments, impacting on quality of life, health and health system expenses.

Regarding the data obtained from the application of the AUFA scale, this allowed the identification of the practice of using diapers in adults, especially in the elderly in the medical clinic sector of the university hospital, the setting of the present study, pointing to an indication without pre established systematic criteria

By indicating the use of diapers and absorbent devices to the individual indiscriminately and without careful evaluation, the risks inherent in the use of this material are assumed, such as IAD, urinary infection, pressure injury, pain and discomfort, and worsening of incontinence urinary and/or faecal. In addition, it makes it difficult to monitor and manage incontinence ${ }^{22 .}$

Therefore, these individuals must be evaluated in a comprehensive way, systematized based on scientific instruments, both for the analysis of global health and identification of the degree of complexity of their care, as well as for specific criteria related to incontinence and the need to use an absorbent device .

In addition, the diagnosis of incontinence should be a priority in the management of these patients with the help of specialists, such as a stomatherapist, to assess the clinical indication, based on technical-scientific precepts, on the real need for the use of absorbent devices.

Thus, avoiding the inadequate implementation of diapers and sanitary pads as a routine of nursing work organization.

Therefore, the practice of nurses needs to be based on theoretical and practical precepts that support decision-making in health and the incorporation of hygiene materials in care. Instruments that systematize the assessment of criteria for the use of diapers in adult patients are essential.

The application of the AUFA scale seems to be an alternative for indicating the use of absorbent devices ${ }^{6,22}$, however, it is necessary to discuss the criteria set out in the scale related to the guidance of the caregiver in the systematization of times for diaper change, specifically every 3 hours, a situation that can determine conflict according to the characteristics of individual incontinence ${ }^{1,6,22}$.

However, without prospective studies evaluating the frequency of diaper change, there is a scientific gap regarding this consensus, a situation that needs to be individualized in relation to intervening variables such as: degree of incontinence, urination volume, skin aspects, pre-existing lesions , mobility, etc.

In addition, each diaper and pad has a degree of absorption and saturation in accordance with the manufacturer's specifications. All of these elements must be taken into account to define the time to change the diaper, so further studies are needed for consensual clinical recommendations.

Thus, broad health education according to good practices in the handling of sanitary pads and diapers based on clinical consensus in health helps institutional policy on quality and patient safety.

Finally, a limitation for this study is the realization of clinical criteria related to diaper use determined by the AUFA scale in a small sample and only one care setting in a university hospital. Despite having addressed the full quantity of patients admitted to the medical clinic during the period of data collection. Above all, the contributions were satisfactory and uncovered a gap in the assistance that must be filled.

Therefore, further studies on the subject are recommended, in addition to cost-effectiveness on the absorbent diaper device related to its clinical application with a greater number of participants, in view of good usage practices. In addition to carrying out the same study in other care scenarios, to assess the AUFA scale with a view to making a decision on diaper indication and handling, including the correct time for changing, with the objective of preventing skin-related complications.

\section{CONCLUSION}

It was possible to conclude with this study that there is a need to implement the systematization of nursing care for the indication and management of the use of pads and diapers in adult patients, mostly elderly.

Inappropriate use or without specific indication should negatively impact health conditions, especially on the skin of these patients and on the cost of health care during their hospitalization. 
The systematization of nursing care added to the use of scales to assess and support decision-making, such as the AUFA scale, will guarantee the patient with incontinence and safe and efficient use of pads or diapers, which is a practice based on scientific evidence.

The scientific basis for care is necessary and reinforced by the National Policy on Patient Safety, which outlines axes for the design of safe health care. Actions aimed at prevention, health promotion and safe use of technologies/materials based on technical-scientific concepts support care decisions.

Absorbents and diapers are hygiene materials added to health care, so their use must be justified, requiring protocols aimed at patient safety, especially with analysis of the user profile, facilitated by instruments such as the AUFA scale.

Therefore, this study made it possible to identify that the indication and even management of pads and diapers by nursing is not yet systematized and based on science. Therefore, the use of the AUFA scale proved to be scientifically relevant to guide the individualized analysis of the clientele.

\section{AUTHORS' CONTRIBUTION}

Conceptualization: Araujo FSF and Di Piero KC; Methodology: Di Piero KC; Research: Araujo FSF and Di Piero KC; Writing-First version: Araujo FSF, Di Piero KC and Cardinelli CC; Writing-Reviewing \& Editing: Araujo FSF, Di Piero KC and Cardinelli CC; Supervision: Di Piero KC.

\section{DATA STATEMENT AVAILABILITY}

All data were generated or analyzed in this study.

\section{REFERENCES}

1. Bitencourt G R. Validação da escala de avaliação do uso de fraldas e absorventes em idosos na atenção primária [tese]. Rio de Janeiro (RJ): Escola de Enfermagem Aurora de Afonso Costa, Universidade Federal Fluminense; 2019.

2. Beeckman D, Van den Bussche K, Alves P, Beele H, Ciprandi G, Coyer F et al. The Ghent Global IAD Categorisation Tool (GLOBIAD). Skin Integrity Research Group - Ghent University. 2017. Available at: www.UCVVGent.be

3. Koudounas S, Bader DL, Voegeli D. Knowledge Gaps in the Etiology and Pathophysiology of Incontinence-Associated Dermatitis: A Scoping Review. J Wound Ostomy Continence Nurs. 2020; 47(4): 388-95. https://doi.org/10.1097/WON.0000000000000656

4. Fernández FPG, Casanova PL, Palma MR, Goméz TS, Agreda JJS. Guia: cuidados de la piel en pacientes con incontinência y prevención de lesiones asociadas de la humedad. Departamento de enfermeria comunitaria, medicina preventiva y salud pública e historia de la ciência; 2016. Available at: https://gneaupp.info/cuidados-de-la-piel-en-pacientes-con-incontinencia-yprevencion-de-lesiones-asociadas-a-la-humedad/

5. Cunha CV, Ferreira D, Nascimento D, Felix F, Cunha P, Penna LHG. Dermatite associada à incontinência em idosos: caracterização, prevenção e tratamento. ESTIMA, Braz J Enterestomal Ther. 2016; 13(3). Available at: https://www.revistaestima.com.br/ estima/article/view/218

6. Bitencourt GR, Santana RF. Evaluation scale for the use of adult diapers and absorbent products: methodological study. Online Braz J Nurs. 2021; 20:e20216466. https://doi.org/10.17665/1676- 4285.20216466

7. Rodríguez-Palma M, Verdú-Soriano J, Soldevilla-Agreda JJ, Pancorbo-Hidalgo PL, García-Fernández FP. Conceptual Framework for Incontinence - Associated Dermatitis Based on Scoping Review and Expert Consensus Process. J Wound Ostomy Continence Nurs. 202;48(3): 239-50. https://doi.org/10.1097/WON.0000000000000754

8. Moraes JT, Borges EL, Lisboa CR, Cordeiro DCO, Rosa EG, Rocha NA. Conceito e classificação de lesão por pressão: atualização no National Pressure Ulcer Advisory Panel. Enferm Cent O Min. 2016;6(2): 2292-2306. https://doi.org/10.19175/recom.v6i2.1423

9. Alves LAF, Santana RF, Cardozo AS, Souza TM, Silva CFR. Dermatitis Associated with Incontinence and the Not-Standard Use of Geriatric Diaper: SystematicReview. ESTIMA Braz J Enterestomal Ther. 2016; 14(4):203-13. https://doi.org/10.5327/Z18063144201600040007

10. Zangirolami-Raimundo J, Echeimberg JO, Leone C. Tópicos de metodologia de pesquisa: Estudos de corte transversal. Journal of Human Growth and Development. 2018;28(3):356-60. https://doi.org/10.7322/jhgd.152198 
11. Polit DF, Beck CT, Hungler BP. Fundamentos de pesquisa em enfermagem: avaliação de evidência para a prática da enfermagem. $7^{\mathrm{a}}$ ed. São Paulo: Artmed; 2011.

12. Folstein MF, Folstein SE, McHugh PR. Mini-mental state: a practical method for grading the cognitive state of patients for the clinician. J Psychiatr Res. 1975;12(13):189-98. https://doi.org/10.1016/0022-3956(75)90026-6

13. Costa TNM, Nieto JPS, Morikawa LS, Araújo AVS, Cardoso AAM, Mafra BG et al. Analysis of Folstein's Mini State examination in institutionalized and non institutionalized elderly people. Brazilian Journal of Health Review. 2021;4(2):8319-36. https://doi. org/10.34119/bjhrv4n2-357

14. Tamanini JTN, Dambros M, D'Ancona CAL, Palma PCR, Rodrigues Netto Junior N. Validation of the "International Consultation on Incontinence Questionnaire - Short Form" (ICIQ-SF) for Portuguese. Rev Saúde Pública. 2004;38(3):438-44. https://doi. org/10.1590/S0034-89102004000300015

15. Timmermans $L$, Falez F, Mélot $C$, Wespes $E$. Validation of use of the international consultation on incontinence questionnaireurinary incontinence-short form (ICIQ-UI-SF) for impairment rating: A transversal retrospective study of 120 patients. Neurourology and Urodynamics 2013;32(7):974-79. https://doi.org/10.1002/nau.22363

16. Yates A. Incontinence-associated dermatitis 1: riskfactors for skindamage. Nursing Times. 2020;116(3):46-50. Available at: https://www.nursingtimes.net/clinical-archive/tissue-viability/incontinence-associated-dermatitis-1-risk-factors-for-skindamage-02-03-2020/

17. Werth SL, Justice R. Prevalence of Moisture-Associated Skin Damage in an Acute Care Setting: Outcomes From a Quality Improvement Project. J Wound Ostomy Continence Nurs. 2019;46(1):51-4. https://doi.org/10.1097/WON.0000000000000499

18. Lopes EB, Pupulim JSL, Oliva APV. Perfil dos diagnósticos de enfermagem de pacientes internados em unidade de clínica médica. Cienc Cuid Saude. 2016;15(2):358-65. https://doi.org/10.4025/cienccuidsaude.v15i2.29356

19. Nobre IEAM, Barros LM, Gomes MLS, Silva LA, Lima ICS, Caetano JÁ. Sistema de classificação de pacientes de FUGULIN: perfil assistencial da clínica médica. Rev enferm UFPE online. 2017;11(4):1736-42. https://doi.org/10.5205/1981-8963v11i4a15245p1736-1742-2017

20. Grden CRB, Martins AR, Cabral LPA, Reche PM, Arcaro G, Brasil D et al. Incontinence associated dermatitis in elderly people admitted to a university hospital. Rev Bras Enferm. 2020;73(Suppl 3):e20190374. https://doi.org/10.1590/0034-7167-2019-0374

21. Malta DC, Bernal RTI, Lima MG, Araújo SSC, Silva MMA, Freitas MIF et al. Doenças crônicas não transmissíveis e a utilização de serviços de saúde: análise da Pesquisa Nacional de Saúde no Brasil. Rev Saude Publica. 2017; 51(Supl 1):4s. https://doi. org/10.1590/S1518-8787.2017051000090

22. Bitencourt GR, Alves LAF, Santana RF. Practice of use of diapers in hospitalized adults and elderly: cross-sectional study. Rev Bras Enferm. 2018;71(2):343-9. http://doi.org/10.1590/0034-7167-2016-0341 